\title{
PENGGUNAAN APLIKASI INSTRUMENTASI PADA PELAYANAN BIMBINGAN DAN KONSELING DI SEKOLAH
}

\author{
Rika Devianti, Suci Lia Sari \\ Program Studi Pendidikan Islam Anak Usia Dini, STAI Auliaurrasyidin Tembilaban \\ e-mail: rika.devianti@stai-tbh.ac.id
}

\begin{abstract}
Abstrak. Lembaga pendidikan merupakan lembaga yang menyediakan berbagai pelayanan bagi peserta didik untuk membantu perkembangan potensi yang optimal. Salah satunya adalah pelayanan Bimbingan dan Konseling (BK) yang merupakan bagian integral dari upaya untuk membantu mengembangkan potensi peserta didik seperti bakat, minat, dan kemampuannya. Salah satu pelayanan yang perlu dilakukan oleh guru BK adalah pelayanan BK dengan kegiatan pendukung, yaitu aplikasi instrumentasi. Namun, tidak semua guru BK memahami penggunaan aplikasi instrumentasi dengan kaitannya pada penempatan dan penyaluran. Tujuan dari penelitian ini adalah untuk mengetahui penggunaan aplikasi instrumentasi dalam layanan dan penyaluran di sekolah. Metode dalam penelitian ini adalah deskriptif kualitatif dengan penelitian kepustakaan. Temuan pada penelitian ini adalah penggunaan aplikasi instrumentasi harus dilakukan oleh guru BK/konselor yang memiliki latar belakang pendidikan S-1 BK, mengikuti pelatihan aplikasi instrumentasi, memahami petunjuk penggunaan dan pelaporan instrumentasi, memahami tahapan instrument mulai dari Koleksi Instrumen; Perencanaan dan Penyiapan Instrumen; Pengadministrasian instrument; pengelolaan dan pemaknaan jawaban responden; Pelaporan atau Penyampaian hasil instrument; Evaluasi;Tindak lanjut atau Penggunaan hasil instrument; dan Pelaksana.
\end{abstract}

Kata kunci: penggunaan aplikasi instrumentasi; pelayanan bimbingan dan konseling

\begin{abstract}
Educational institutions are institutions that provide various services for students to foster optimal potential. One of them is the guidance and counseling (BK) service which is an integral part of efforts to help develop the potential of learners such as their talents, interests, and abilities. One of the services that needs to be done by counseling teachers is counseling service with supporting activities, namely instrumentation applications. However, not all ble teachers understand the use of instrumentation applications in relation to placement and distribution. The purpose of this study was to determine the use of instrumentation applications in service and distribution in schools. The method in this research is descriptive qualitative with library research. The findings in this study are the use of instrumentation applications must be done by counseling teachers / counselors who have a bachelor degree education background, attend instrumentation application training, understand instrumentation usage instructions and reporting, understand instrument stages starting from the instrument collection; instrument planning and preparation; administering the instrument; management and meaning of respondent answers; reporting or submitting of instrument results; evaluation: follow up or use of instrument results; and implementing.
\end{abstract}

Keywords: The use of instrumentation; guidance and counseling services 


\section{PENDAHULUAN}

Sekolah merupakan lembaga formal yang dibentuk untuk menyelenggarakan pendidikan bagi seluruh masyarakat dengan harapan dapat mengembangkan perkembangan secara optimal bagi setiap peserta didik. Harapan tercapainya perkembangan yang optimal, setiap lembaga pendidikan menerapkan berbagai pelayanan yang dilaksanakan oleh guru-guru yang berkopetensi dibidangnya masing-masing. Salah satunya guru BK sebagai pelaksana pelayanan bimbingan dan konseling di sekolah yang memberikan bimbingan kepada peserta didik untuk membantu mengatasi masalah yang berkaitan pribadi, social, karir, berkeluarga, dan beragama, serta mampu membantu mengembangkan potensi secara tepat.

Sebagaimana yang tercantum pada UU No. 14 tahun 2005 tentang guru dan dosen Bab IV Pasal 8 "guru wajib memiliki kualifikasi akademik, kompetensi, sertifikat pendidik, sehat jasmani dan rohani, memiliki kemampuan untuk mewujudkan pendidikan nasional" (Depdiknas, 2005). Hal ini tidak terlepas dari pencapaian tujuan pendidikan nasional sebagaimana yang tercantum pada UU No. 20 tahun 2003 tentang Sistem Pendidikan Nasional, pasal 3, tujuan pendidikan nasional adalah mengembangkan potensi peserta didik agar menjadi manusia yang beriman dan bertakwa kepada Tuhan Yang Maha Esa, berakhlak mulia, sehat, berilmu, cakap, kreatif, mandiri, dan menjadi warga Negara yang demokratis serta bertanggung jawab" (Depdiknas, 2003). Menelaah dari kalimat yang tertuang pada undang-undang tersebut di atas, maka guru BK ditekankan agar menjadi guru yang professional dan dinamis, mampu berfikir kritis, kreatif, cerdas, dan penuh pengabdian dalam menjalankan pelayanan BK.

Penyelenggaraan BK di sekolah merupakan bagian integral dari upaya pendidikan yang berperan aktif untuk membantu mengembangkan potensi seperti, bakat, minat, dan kemampuan peserta didik. Sebagaimana yang tertuang dalam Permendiknas No. 22/2006 tentang standard isi dan satuan pendidikan dasar dan menengah, pelayanan konseling: a. memberikan kesempatan kepada peserta didik untuk mengembangkan dan mengekspresikan diri sesuai dengan kemampuan, bakat, dan minat; b. masalah pribadi, kehidupan social, belajar, dan pengembangan karir; dan c. difasilitasi/dilaksanakan oleh konselor (Depdiknas, 2006).

Bimbingan yang diberikan tentunya berbeda antara satu dengan yang lainnya, hal ini dikarenakan setiap peserta didik itu unik, tentunya pelayanan yang diberikan juga menyesuaikan dengan keunikan siswa tersebut. Untuk mengetahui perbedaan tersebut, guru BK perlu memperoleh data atau informasi peserta didik. Seperti data identias diri, catatan hasil sekolah atau hasil tes maupun data atau informasi lainnya yang dirasa penting. Untuk mengetahui data atau informasi tersebut dilakukan kegiatan pendung yaitu aplikasi instrumentasi. Aplikasi instrumentasi merupakan pengumpulan data diri peserta didik yang bersifat rahasia. 
Aplikasi instrumentasi BK merupakan upaya pengungkapan yang dilakukan oleh guru BK melalui pengukuran yang dilakukan dengan menggunakan alat ukur atau instrument tertentu (Tohirin, 2007). Aplikasi instrumentasi ini dilaksanakan dalam bentuk tes dan non-tes. Dalam bentuk tes dilaksanakan oleh lembaga psikologi, seperti tes psikologis, sedangkan non-tes, dilaksanakan oleh guru BK seperti, wawancara, observasi, angket, inventori tugas perkembangan, sosiometri, AUM Umum, dan AUM PTSDL.

Aplikasi instrumentasi dapat dipandang sebagai kegiatan utama dan pertama dalam layanan bimbingan dan konseling. Utama dimaknai sebagai penting dan tidak bias ditingggalkan. Artinya seluruh layanan bimbingan dan konseling tidak akan berjalan dengan baik tanpa didahului pemahaman diri dan lingkungan siswa. Pemahaman tersebut hanya akan terjadi jika konselor memiliki data atau informasi siswa yang diperoleh melalui kegiatan aplikasi instrumentasi tersebut. Pertama karena kegiatan aplikasi instrumentasi merupakan kegiatan terawal dari kegiatan bimbingan yang lainnya (Putera \& Muls, 2013).

Hasil dari aplikasi instrumentasi dianalisis dan ditafsirkan kemudian digunakan untuk memberikan bimbingan secara tepat dengan pelaksanaan layanan BK. Salah satunya instrumentasi ini diperlukan dalam layanan penempatan dan penyaluran siswa di sekolah, baik penempatan dan penyaluran bakat, minat, dan kemampuannya pada penjuruasan atau pada kegiatan ekstakurikuler yang ada di sekolah atau pada jenjang pendidikan selanjutnya. Dengan demikian, guru BK perlu memahami diri klien seutuhnya untuk memudahkan guru BK dalam pembuatan program layanan BK baik bersifat preventif, pengembangan, dan kuratif. Sebagaimana yang dinyatakan oleh Tohirin (2007) bahwa sebaiknya perencaan program pelayanan bimbingan dan konseling di sekolah disusun berdasarkan data yang diperoleh melalui aplikasi instrumentasi. Pendapat ini juga didukung oleh Prayitno (2004) bahwa hasil instrumentasi baik sebagian atau seluruhnya, secara langsung atau tidak langsung dapat dijadikan isi layanan yang hendak dilaksanakan atau sedang dilaksanakan terhadap klien.

Pentingnya pemahaman dan kemampuan guru BK dalam penggunaan aplikasi instrumentasi di sekolah merupakan bimbingan utama bagi peserta didik untuk dapat diarahkan potensinya secara tepat. Namun, pada beberapa kasus guru BK di beberapa sekolah tergambar dari berbagai penelitian bahwa guru BK masih memiliki berbagai persoalan dalam penggunaan aplikasi instrumentasi tersebut, seperti hasil temuan Sundari dan Satrio BW adalah dari 5 Sekolah Menengah Pertama, diketahui bahwa masih kurangnya kemampuan guru BK dalam melakukan kegiatan aplikasi instrumentasi, hal ini terlihat dari hasil penelitiannya sebagai berikut, penguasaan aplikasi instrumentasi memiliki persentase terendah adalah aspek pelaksanaan dan laporan, yaitu 15-16\%; dan kuarngnya pemahanan guru BK dalam penggunaan aplikasi instrumentasi yang 
disebabkan oleh latar belakang pendidikan yang tidak sesuai, belum banyak pengalaman, dan kurangnya pelatihan (Siti Sundari \& Satrio, 2014). Selanjutnya dari hasil penelitian Muhammad Putra Dinata Saragi yang menyebutkan bahwa ada beberapa hambatan yang ditemukan dalam pelaksanaan aplikasi instrumentasi di sekolah, yaitu hambatan dari dalam diri sendiri yaitu pada pelaksaan dan pengolahan AUM UMUM dan AUM PTSDL, karena sulit menjelaskan petunjuk pengisian AUM PTSDL kepada siswa dan sulit menetapkan alokasi waktu untuk melaksnakannya, kemudian hambatan dari luar diri yaitu tidak tersedianya kelengkapan penunjang teknis, tidak tersedianya waktu yang terjadwal untuk pelayanan BK, tidak tersedianya buku AUM, tidak tersedianya perlengkapan administrasi, dan tidak tersedianya anggaran dana yang cukup (Muhammad Putra, 2018).

Lebih lanjut, penelitian tentang pelaksanaan aplikasi instrumentasi di SMA Negeri seKabupaten Pati, ditemukan pada indicator perencanaan, pelaksanaan, evaluasi, analisis hasil, dan pelaporan, berdasarkan analisis deskriptif diperoleh rata-rata persentase sebesar $57 \%$ dan termasuk pada kriteria sedang. Artinya, pelaksanaa aplikasi instrumentasi secara umum kurang baik (Fitriani \& Heru, 2016). Senada dengan itu, penelitian yang dilakukan di epat sekolah SMP dan SMA menunjukkan bahwa pelaksanaan aplikasi instrumentasi terlaksana tetapi tidak optimal karena kurangnya personil BK dan waktu yang kurang memadai (Juftiar \& Tamsil, 2013). Atas dasar inilah maka penulis tertarik untuk meneliti tentang penggunaan aplikasi instrumentasi pada pelayanan bimbingan dan konseling di sekolah.

\section{METODE}

Penelitian ini menggunakan pendekatan deskriptif kualitatif dan jenis penelitian yang digunakan adalah pendekatan kepustakan (library research), yaitu mengumpulkan data atau karya ilmiah yang berkaitan dengan objek penelitian. Menurut Mustika (2003) pendekatan kepustakaan atau studi pustaka adalah serangkaian kegiatan yang berkenaan dengan metode pengumpulan data pustaka, membaca, dan mencatat dan mengolah bahan penelitian.

Berdasarkan hal tersebut maka pengumpulan data dalam penelitian ini dilakukan dengan menelaah atau mengeksplorasi beberapa jurnal, buku-buku, dan dokumen-dokumen (baik yang berbentuk cetak maupun elektronik) serta sumber data atau informasi yang dianggap relevan dengan penelitian ini. 


\section{HASIL}

\section{Aplikasi Intrumentasi Bimbingan dan Konseling di sekolah}

\section{Pengertian Aplikasi Instrumentasi}

Aplikasi instrumentasi merupakan cara yang efektif untuk memahami tentang diri pribadi klien dan masalah yang dihadapinya. Aplikasi instrumentasi merupakan salah satu kegiatan yang mendukung pelaksanaan binmbingan dan Konseling disekolah dengan kegiatan pendukung konselor dapat menjalankan tugas tugas pelayanannya. Aplikasi instrumentasi akan membantu guru BK memahami klien baik secara pribadi, social, belajar, karir, kehidupan berkeluarga dan kehidupan beragama.

Menurut Prayitno (2004) instrumentasi merupakan salah satu rencana yang perlu dikembangkan agar pelayanan bimbingan dan konseling disekolah terlaksana secara lebih cermat dan berdasarkan data yang empirik. Intrumentasi yang dipakai harus sahih dan terandalkan. Pemilihan instrument yang akan dipergunakan berdasarkan tepat guna dan tujuan yang hendak dicapai dalam pelaksanaan BK disekolah. Selanjutnya, menurut Anas Salahudin (2010) aplikasi instrumentasi merupakan kegiatan penunjang untuk pelaksanaan bimbingan dan konseling di sekolah, yaitu kegiatan mengumpulkan data tentang diri siswa dan lingkungannya, melalui aplikasi berbagai instrumen, baik tes maupun nontes.

Dari beberapa pengertian di atas dapat disimpulakn aplikasi instrumentasi merupakan salah satu kegiatan pendukung atau penunjang pelaksanaan layanan bimbingan dan konsling disekolah, untuk mengumpulkan data siswa sehingga guru BK bisa memahami diri sisawa dan permasalahan yang sedang dialami, intrumen yang dipakai hendaklah akurat sehingga data dapat memberikan data tepat tentang individu, sehingga layanan bimbingan dan konseling lebih efektif.

Fungsi utama instrumentasi adalah untuk mengumpulkan data. Dalam berbagai keperluan ilmiah data, berupa keterangan atau informasi tentang suatu benda atau non benda. Informasi atau keterangan tersebut dapat berupa ukuran, besaran, angka atau secara deskripsi, uaraian dan kualifikasi tentang pribadi seseorang. Pemberian bimbingan akan efektif jika didasarkan data yang akurat. Jika konselor ingin nelakukan kegiatan bimbingan secara efektif, maka dia harus mengetahui segala sesuatu yang ada pada peserta didiknya (Furkin dalam Mamat, 2013). Bentuk aplikasi instrumentasi dalam pelaksanaan BK, berupa tes dan non-tes. Berikut pemaparan bentuk tes dan non-tes tersebut: 
1) Tes

Menurut Cronbach dalam Prayitno (2014: 318) tes merupakan prosedur untuk mengungkapkan tingkah laku individu dan mengaggambarkan berbentuk skala angka atau klasifikasi tertentu. Tes merupakan serangkaian pertanyaan tertulis ata lisan dan harus dikerjakan oleh testi, tes ini bertujuan untuk mengukur suatu aspek prilaku testi. Macam-macam tes, Tes hasil belajar; Tes intelegensi; Tes bakat; Tes minat; Tes kpribadian; Dan tes diaknostik.

\section{2) Non Tes}

Selain tes, aplikasi instrumetasi bisa juga menggunakan bentuk non tes, perbedaan tes dan nontes adalah tes ada jawaban benar dan salah, sedangkan nontes jawaban salah sangat kondisional; hasil tes lebih kuantitatif, sedangkan non tes kualitatif; dan pelaksanaan tes adalah orang yang professional, sedangkan non tes tidak selamanya orang yang professional. (Mamat, 2013).

Non tes meliputi berbagai prosedur, seperti pengamatan dan wawancara, catatan, anekdot, angket, sosiometri, dan inventori yang dibakukan. Agar memperoleh hasil yang akurat hendaknya menggunakan pedoman pengamatan atau wawancara. Catatan anekdot merupakan hasil pengamatan, khususnya tentang tingkah laku yang tidak biasa atau khusus yang perlu mendapatkan perhatian tersendiri. Angket dan daftar isian digunakan untuk mengungkap tentang diri individu oleh individu sendiri. Sosiometri untuk melihat dan memberikan gambaran tentang hubungan social antara individu, dengan sosiometri akan terungkap mana yang terisolir dan yang terpopuler. Dan sedangkan inventori untuk mengungkap jenis masalah yang dialami, sikap dan kebiasaan belajar individu. (Prayitno, 2014)

\section{Konstruksi Instrumen}

Suatu instrument dibangun atas dasar konstruksi. Biasanya dikembangkan dari teori tertentu, langkah yang dapat kita lakukan dalam mengembangkan instrument adalah pertama menetapkan landasan teori. Secara ilmiah perlu adanya landasan teori, kita contohkan jika ingin membuat instrument tes minat, maka lahngkah yang perlu diambil pertama "teori siapa yang akan dipakai untuk mengembangkan istrumen", kite perlu mencari teori tentang minat, dan teori tersebut benar benar akan dapat di ukur, kedua memikirkan alat ukur atau model apa yang akan dikembangkan, ketiga perlu memikirkan bentuk instrument yang akan dikembangkan, jika ingin mengembangkan bentuk tes, perlu untuk mengikuti prosedur pengembangan alat ukur tes, begitu juga intrumen non tes, dan keempat mengembangkan kisi-kisi. Setelah mendapatkan teori, kita perlu membuat kisi-kisi untuk memudahkan pengembanga instrument, dari variable, sub varibel, indicator, sub indicator, dan Item pertanyaan atau pernyataan. 
Prosedur Mengembangkan Instrumen tes dan non tes berupa (mamat, 2013), pertama mengembangkan kisi-kisi. Setelah mendapatkan teori, kita perlu membuat kisi-kisi untuk memudahkan pengembangan instrument, dari variable, sub varibel, indicator, sub indicator, dan Item pertanyaan atau pernyataan; kedua menetukan format instrument yang akan digunakan. Menentukan format mana yang akan digunakan, wawancara, tes atau yang lain. Kemudian juga bisa menetukan bentuk pertanyaan atau pernyataan mau seperti uraian, pilihan atau skala atau yang lainnya, ketiga mengembangkan konstruk memngembangkan teori-teori apa yang ingin kita ukur, keempat menulis atau merumuskan item-item sesuai dengan format yang dipilih. Setelah item-item dibuat menurut teori yang sudah ditentukan, selanjutnya memasukan item-item tersebut dalam bentuk format yang sudah ditentukan, kelima mengkaji ulang rumusan item-item instrument oleh staf lain (judgment.) memberikan instrument yang telah dibuat kepada ahli dalam bidang yang berkaitan dengan instrument yang sudah dikembangkan. Judgment merupakan validitas instrument. Para ahli tersebut menilai dan mempertimbangkan isi instrument sesuai dengan batasan domain ukur yang telah ditetapkan dan sesuai dengan akan diungkap. Para ahli juga menilai sejauh mana suatu instrument mengukur konstruk teoritis yang akan diukur, keenam merevisi item-item instrument berdasarkan hasil judgment. Setelah dinilai dan dipertimbangkan para ahli, item-item instrumen diperbaiki sesuai saran, ketujub menggandakan instrument. Memperbanyak instrument sesuai kebutuhan, sehingga memudahkan ketika dalam pengumpulan data, dan kedelapan kelapangan (pengumpulan data). Memberikan instrument kepeda yang ingin diungkap.

\section{Penggunaan Aplikasi Instrumentasi dalam Pelayanan Bimbingan dan Konseling di Sekolah}

Berdasarkan hasil penelitian, aplikasi instrumentasi merupakan hal yang penting baik ditinaju dari segi kegunaan dan tujuan bagi konselor dan peserta didik. Selain itu pengaplikasian yang tidak tepat menjadikan ketidakakuratan dalam mengukur masalah dan kebutuhan peserta didik, hal ini mengharuskan guru BK memahami setiap proses tahapan pada pengaplikasiannya dengan tujuan aplikasi instrumentasi dapat berjalan dengan baik, masalah dan kebutuhan peserta didik dapat diatasi dan mereka dapat berkembang secara mandiri dan mampu mencapai aktualisasi diri sesuai dengan tahap perkembangannya.

Dalam hal ini akan dipaparkan beberapa tahapan penggunaan aplikasi instrumentasi yang perlu dikuasai oleh guru BK atau konselor di sekolah, yaitu: Koleksi Instrumen; Perencanaan; Pelaporan; Evaluasi; Tindak lanjut; dan Pelaksana (Juftiar \& Tamsil, 2013). Selanjutnya tahapan aplikasi instrumentasi menurut Tohirin, (2004). 


\section{Penyiapan Instrumen}

Dalam penyiapan instrument ada beberapa hal yang perlu diperhatikan dan dipersiapkan oleh guru BK, yaitu mempelajari manual instrument; mengidentifikasi karakteristik siswa; melihat kesesuaian antara instrument dan siswa; menyiapkan diri untuk mampu mengadministrasikan instrument; dan menyiapkan aspek teknik dan administrasi.

\section{Pengadministrasian instrument}

Dalam hal ini, guru BK mengemukakan: pokok isi, bentuk, tujuan, dan kegunaan instrument bagi siswa; bagaimana bekerja dengan instrument tertentu, termasuk alokasi waktu yang disediakan; bagaimana mengolah jawaban responden; bagaimana hasil pengolahan itu disampaikan kepada siswa; dan bagaimana hasil tersebut digunakan dan apa yang perlu atau diharapkan dilakukan oleh responden.

\section{Pengelolaan dan pemaknaan jawaban responden}

Pengolahan jawaban responden dapat dilakukan secara manual dan dapat menggunakan peralatan elektronik seperti program computer. Data atau jawaban responden yang sudah diolah baik secara manual maupun computer, selanjutnya dianalisis atau dimaknai dengan menggunakan kriteria tertentu yang telah ditetapkan, selanjutnya siap digunakan dalam rangka pelayanan bimbingan dan konseling.

\section{Penyampaian hasil instrumen}

Hasil instrument harus disampaikan secara cermat dan hati-hati. Asas kerahasiaan haru benar diterapkan. Hasil aplikasi instrumentasi tidak boleh diumumkan secara terbuka dan tidak boleh dijadikan konsumsi atau pembicaraan umum apalagi kalau didalamnya terdapat nama siswa. Hasil instrumentasi boleh dikonsumsi umum dan didiskusikan secara terbuka, misalnya disajikan atau didiskusikan di dalam kelas tetapi tidak satu namapun disebutkan dan tidak satu datapun dikaitkan dengan pribadi tertentu. Hasil instrument tertentu dapat dijadikan sebagai pertimbangan untuk memanggil individu (siswa) dalam rangka pelayanan bimbingan dan konseling sesuai dengan hakikat dan prinsip bimbingan dan konseling, yang dipanggil bukan hanya para siswa yang diindikasikan bermasalah seperti sekor rendah, mereka yang memiliki skor tinggi juga perlu mendapatkan layanan. 


\section{Penggunaan hasil instrumen}

Hasil-hasil instrument dapat digunakan bagi perencanaan program bimbingan, penetapan peserta layanan, sebagai isi layanan, tindak lanjut, dan bagi upaya pengembangan.

Penggunaan aplikasi instrumentasi yang baik tentunya tidak terlepas dari berbagai tahapan atau teknik dalam penggunaannya. Maka, tahapan-tahapan tersebut harus benar-benar menjadi perhatian penting, baik guru BK, Kepala sekolah, guru-guru atau TU bahkan semua stakeholder di sekolah juga memberikan sumbangsih saling memahami, memberikan dukungan, dan saling bekerja sama dalam proses kegiatan aplikasi instrumentasi agar kegiatan tersebut dapat berjalan dengan efektif. Hal ini juga diperkuat dengan latar belakang akademik guru BK seperti yang tertuang pada Depdiknas (2008) bahwa kualifikasi kompetensi akademik pendidik guru bimbingan dan konseling minimal Sarjana Pendidikan (S-1) dalam bidang bimbingan dan konseling. Sedangkan kompetensi professional merupakan penguasaan kiat penyelenggaraan bimbingan dan konseling yang memandirikan, yang ditumbuhkan, serta diasah melalui latihan menerapkan kompetensi akademik yang telah diperoleh dalam konteks otentik Pendidikan Profesi Konselor (PPK) yang berorientasi pada pengalaman dan kemampuan praktik lapangan, dan tamatannya memperoleh sertifikat profesi bimbingan dan konseling dengan gelar profesi Konselor, disingkat Kons.

Guru BK bertanggungjawab untuk menjelaskan pengisian instrument sedangkan peserta didik berhak untuk mendapatkan pemahaman yang jelas. Menurut Nana dan Ibrahim, (2011) menyatakan kompetensi guru BK dalam menjelaskan tentang instrument tersebut kepada siswa merupakan suatu keharusan, menjelaskan petunjuk atau cara pengisian angket supaya tidak terjadi kesalahan, kalau perlu berikan contoh kepada responden. Hal ini seyogyanya sangat diperlukan agar responden tidak mengalami kebingungan dalam pengisian angket tersebut. Hal senada diungkapkan oleh Prayitno (2006) bahwa untuk itu guru BK perlu mempelajari manual instrument agar nantinya dapat menjelaskan kepada responden dengan benar dan tepat.

Hal ini diupayakan agar proses pelaksanaan aplikasi instrumentasi berjalan dengan lancar dan sesuai dengan waktu yang telah ditentukan, karena beban kerja guru BK dalam pelaksanaan layanan bimbingan dan konseling sesuai dengan jam kerja guru BK, sebagaimana yang tertuang pada Permendikbud Nomor 111 Tahun 2014, jam kerja guru BK dihitung dengan rasio 1: (150160) ekuivalen dengan jam kerja 24 jam. Guru BK yang rasio tugas dengan konseli kurang dari 1:150 maka jam kerjanya dapat dihitung dengan menggunakan satuan jam kinerja profesi BK. Yaitu, melaksanakan berbagai kegiatan profesi BK dengan bukti fisik kegiatan yang terdokumentasikan. 


\section{SIMPULAN}

Dari pemaparan hasil penelitian di atas dapat disimpulkan bahwa penggunaan aplikasi instrumentasi pada layanan bimbingan dan konseling merupakan hal utama dan yang mendasar untuk dilaksanakan oleh guru BK kepada peserta didik. Titik awal memberikan bantuan pada pemecahan masalah dan pemenuhan kebutuhan dalam membimbing peserta didik dalam mengembangkan perkembangan potensi secara tepat dan mandiri. penelitian ini, mengupayakan permasaan kemampuan dalam pengaplikasian instrument yang merupakan jendela untuk melihat berbagai perbedaan setiap peserta didik, untuk diberikan bimbingan yang tepat. Maka, hal yang begitu utama dan urgent untuk dipahami adalah tahapan ataupun teknik dalam pelaksanaan aplikasi instrumentasi tersebut. Seperti, koleksi instrumen; perencanaan dan penyiapan instrumen; pengadministrasian instrument; pengelolaan dan pemaknaan jawaban responden; pelaporan atau penyampaian hasil instrument; evaluasi; tindak lanjut atau penggunaan hasil instrument; dan pelaksana.

Kemudian menindaklanjuti hasil penelitian ini, diharapkan kepada lembaga pendidikan untuk mengevaluasi kembali latar belakang pendidikan guru BK, mengikuti berbagai pelatihan pengaplikasian instrument baik secara manual maupun computer, memperhatikan beban kerja yang seharusnya, dan saling mengutamakan kerjasama diantara stakeholders, mulai dari Koordinator BK, Guru BK, Kepsek, Guru-guru, Tata Usaha, Dinas Pendidikan, dan pihak-pihak yang terkait yang mungkin mampu memberikan sumbangsih bersifat membangun dan mengikuti perubahan perkembangan dalam membantu guru-guru BK dalam melaksanakan aplikasi instrumentasi pada pelayanan bimbingan dan konseling, sehingga pelaksanaan dan penggunaan aplikasi instrumentasi dapat berlangsung dengan efektif.

\section{REFERENSI}

Anas Salahudin. 2010. Bimbingan dan konseling. Bandung: Pustaka Mutia.

Departemen Pendidikan Nasional. 2003. Undang-Undang Nomor 20 Tabun 2003 tentang Sistem Pendidikan Nasional. Jakarta: Depdiknas.

Depdiknas. 2006. Permendiknas No 22 Tabun 2006 Tentang Standar Isi. Jakarta: Depdiknas.

Depdiknas. 2008. Penataan Pendidikan Profesional Konselor dan Layanan Bimbingan dan Konseling dalam Jalur Pendidikan Formal. Jakarta: Depdiknas.

Fitriani Chairunnisak \& Heru Mugiarso. 2016. "Pelaksanaan Aplikasi Instrumentasi di SMA Negeri se-Kabupaten Pati". Jurnal Indonesian Journal of Guidance and counseling: Theory $n$ Aplication. 5 (1). Jurusan BK: Universitas Negeri Semarang.

Juftiar Mahendra Zainur Putra \& Tamsil Muis. 2013. "Studi Tentang Pelaksanaan Aplikasi Instrumentasi Bimbingan dan Konseling di SMP dan SMA Negeri Kota Sumenep". Jurnal Mahasiswa Bimbingan dan Konseling. Vol. 1. No. 1. (Online) https://media.neliti.com rabu, 22 juli 2020. 
Mamat Supriatna. 2013. Bimbingan dan Konseling Berbasis Kompetensi. Jakarta: Rajawali Pers.

Mestika Zed. 2003. Metode Penelitian Kepustakaan. Jakarta: Yayasan Obor Indonesia.

Muhammad Putra Dinata. 2018. "Pelaksanaan Aplikasi Instrumentasi”. Jurnal Bimbingan Konseling Islam. Vol. 1. No. 1.

Nana Sudjana \& Ibrahim. 2011. Penilaian Hasil Proses Belajar Mengajar. Bandung: Remaja Rosdakarya.

Prayitno \& Erman Amti. 2004. Dasar-dasar Bimbingan dan Konseling. Jakarta: Rineka Cipta.

Prayitno. 2006. Seri Kegiatan Pendukung Konseling (PI-P6). Padang: UNP Press.

Putera, J.M., \& Muis, T. 2013. "Studi Tentang Pelaksanaan Aplikasi Instrumentasi Bimbingan dan Konseling di SMP dan SMA Negeri Kota Sumenep". Jurnal Mahasiswa Bimbingan Konseling. Vol $1 \quad$ No $1 . \quad$ http://jurnalmahasiswa.unesa.ac.id/index.php/jurnal-bk unesa/article/view/1937/5343

Siti Sundari dan Satrio Budi Wibowo. 2014. "Tingkat Penguasaan Aplikasi Instrumentasi Guru Bimbingan dan Konseling SMP di Kota Metro". Artikel.

Sujadi, Eko. (2018). Kode Etik Profesi Konseling Serta Permasalahan dalam Penerapannya. Tarbawi: Jurnal Ilmu Pendidikan, 14(2), 69-77. https://doi.org/10.32939/tarbawi.v14i2.298

Tohirin. 2007. Bimbingan dan Konseling di Sekolah dan Madrasah. Jakarta: PT Raja Grafindo Persada. 